\title{
Contents Vol. 43 (1-3)
}

Editorlal article - $\quad$ - $\quad$ - $\quad$ - $\quad$ - $\quad$ - $\quad$ - Page

Water, Forests and Government Organization

A. T. Prince

Think of the Consequences

L. R. Thiesmeyer - - - - - - - - - - 15

Federal and Provincial Forest Policies in Canada

I. Z. Rousseau - - - - - - - - - - - 21

Water Management in Canada

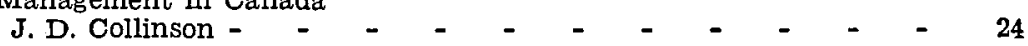

Control of Water-Key to Industrial and Agricultural Development

R. E. Bailey - - - - - - - - - - - 34

Water Yield Improvement Research in Canada: Needs and Future Trends

W. W. Jeffrey - - - - - - - - - - - 39

Forest Management Forum: Opening Remarks

Alan Moss

Current Legislation by Provinces as it Affects the Advance Toward the

Goal of Management D. P. Drysdal Forest Exploitation - Extensive-Intensive Forest Management

Management Priorities and Means to Accomplish

J. S. Stokes - - - - - -

Obstacles and Incentives in Management Practice

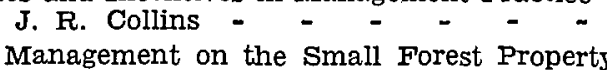

Forest Management on the Small Forest Property

Forest Management Forum: Summary of Discussion

Alan Moss - - -

A. W. Jackson - - - - - - - - - - -84

Future Application of Meteorology in Fire Control

D. E. Williams -

News and Notes

Joint CIF/SAF Annual Meeting, Ottawa, October 15-19, 1967 - $\quad$ - 93

Biennial Meeting on Tree Breeding, Vancouver, 1966 - $\quad$ - 95

K. G. Fensom Appointed National CIF Historian - - - $\quad$ - 97

Forest History Records Moved - $\quad$ - $\quad$ - $\quad$ - 97

Forestry Memorial Scholarship, Toronto - - - - $\quad$ - 98

The Foresters Role in Resources Management - $\quad$ - $\quad$ - $\quad$ - 99

Comments on Godwin's Paper - - - - - - $\quad$ - 101

Obituary: Dr. John Ertel Bier - - - - - - - - 104

Reviews

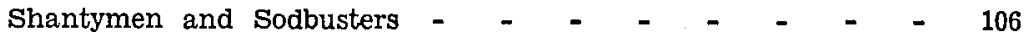

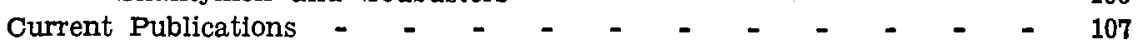

Membership - - - - - - - - - - - - - 110

Employment Opportunities - - - - - - - $\quad$ - $\quad$ - 112 


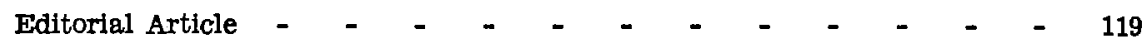

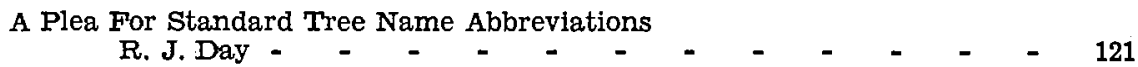

The Ups And Downs Of Pioneer Planting Research In Louisiana--Problems In The Design And Analysis of Planting Trials

Philip O. Wakeley - - - - - - - - - - 135

Direct Measurement Of Internal Moisture Deficits In Trees

Geoffrey Pierpoint - - - - - - - - - - 145

Improved Germination of White Spruce Seed By Increasing Moisture Content With Absorptive Powders

R. M. Waldron and J. H. Cayford - $\quad$ - $\quad$ - $\quad$ - $\quad$ - 149

Root Exposure Of White Spruce Nursery Stock

R. E. Mullin - - - - - - - - - - - 155

Scleroderris Lagerbergii Gremmen, A New Threat To Nurseries In Northern Ontario

David Punter

Influence Of Specific Gravity And Growth Rate On Dry Wood Production In Plantation-Grown White Spruce

C. I. Chang and R. W. Kennedy

Establishment And Early Development of White Spruce In The Interior Of British Columbia

S. Fis

The Optimum Forest Rotation

P. H. Pearse

News And Notes

Plans for 1967 TAPPI Forest Biology Conference in Montreal - -

Report on Poplar Symposium, Hot Springs, B.C.

February 21-23, 1967 - - - $\quad$ - $\quad$ - $\quad$ - 196

Entomological Society of Canada Annual Meeting, 1967 - $\quad$ - 201

For the Sake of Argument

Alan D. Chambers - $-\quad$ - $\quad$ - $\quad$ - $\quad$ - $\quad$ - $\quad$ - 202

Obituaries - W. G. E. Brown, Dr. John E. Bier, Oscar G. Larsson, Major

General Howard Kennedy - - - - - - - - 203

Institute Affairs - New Secretary-Manager of the C.I.F. - - - - 206

Proposed Changes in C.I.F. Publications - - $-\quad-\quad-\quad-\quad-207$

Book Reviews

North America - - $\quad$ - $\quad$ - $\quad$ - $\quad$ - $\quad$ - $\quad$ - 209

Harvesting Timber Crops - - - - - - $-\quad-\quad 210$

Current Publications - $\quad$ - $\quad$ - $\quad$ - $\quad$ - $-\quad$ - - - $\quad 212$

Membership - $\quad$ - $\quad$ - $\quad$ - $\quad$ - $\quad$ - $\quad$ - $\quad$ - $\quad$ - 216 
Editorial Article - _ _ _ _ _ - _ _ _ - - 221

Heart Rot of Jack Pine in Ontario. III. Decay Relationships

and Their Effects on Management

J. T. Basham - - - - - - - - - - - 222

Spraying Too Early Damages Pine Plantations

N. R. Walker - - - - - - - - - - - 239

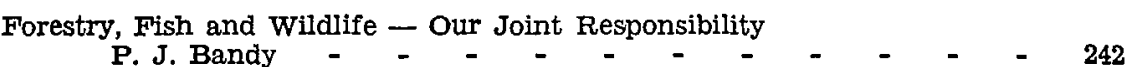

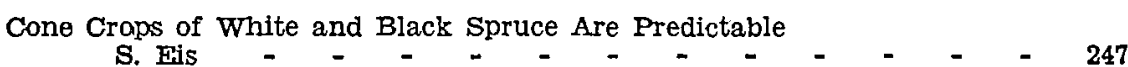

Research Needs of Peatland

J. K. McEwen - - - - - - - - - - - 253

A Comparison of Actual and Potential Forest Land Production

in Saskatchewan

A. Kabzems and J. P. Senyk - - - - - - - - 257

Selectivity of Herbicides

R. F. Sutton - - - - - - - - - - - 265

The Trairing and Qualifications of the Forest Engineer in Quebec Marcel Lortie - - _ - _ - _ _ - - 269

Whitebark Pine in the Rocky Mountains of Alberta

R. J. Day

News and Notes

Notes on Forest Fertilization Symposium, Gainsville, Florida

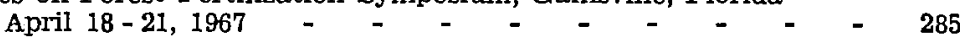

Third North American Soils Conference, 1968 - - - - 290

Possible Contributions of Timber Production Forestry to Economic Development

For the Sake of Argument

Correspondence on Forestry a la Madison Avenue

A. P. MacBean; J. C. W. Irwin; J. I. Farrar; D. I. Crossley - 292

Institute Affairs

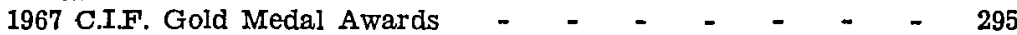

Schlich Memorial Award, 1967 - $-\quad-\quad-\quad-\quad-\quad-299$

Reforestation on Public Sustained Yield Units in the
Coastal Regions of British Columbia - - -300

Reviews

Timber Production by Forest Fertilization - - - - - 304

The Genus Pinus - - - - - - - - - - 305

Forest Management. Regulation and Valuation - - - - 306

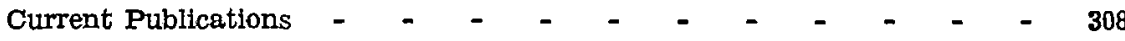

Membership

Continued on Page 314 